\title{
ON A COLLECTION OF PAPPATACI FLIES (PHLEBOTOMUS) FROM INDIA
}

\author{
BY \\ PROFEsSoR R. NEWSTEAD, F.R.S., \\ AND \\ MAJOR J. A. SINTON, V.C., I.M.S. \\ (Received for publication I4 March, I92I)
}

The collection of insects which form the subject of this communication was made by one of us (J. A. Sinton) in the North-west Province of India, with the exception of the single capture of a specimen of Phlebotomus major, Annandale, at Simla. It embraces the records of a very large number of individuals (664) representing three species and one variety, and, as the pappataci flies of the region in question have not hitherto been investigated, it seemed desirable that a complete list of the captures should be recorded, the subject being a cognate one to that of pappataci fever.

The occurrence of Phlebotomus sergenti, Parrot, is of much interest, the species being a new addition to the fauna of India.

In the examination of the long series of examples of Phlebotomus minutus, Rond., it was found to be impossible to draw any hard and fast lines for the separation of this species from P. antennatus, Newst., 1 since we found so many intermediate forms ranging between typical examples of each. It may be recalled that the erection of $P$. antennatus was based chiefly upon the remarkably short antennal segments, and the relatively shorter legs; the male genital armature on the other hand being absolutely identical with that of typical $P$. minutus. It seems, therefore, that the differences in the antennal segments can no longer be considered as of specific importance; $P$. antennatus has therefore been placed as a variety of $P$. minutus.

We tender out thanks to Miss Alwen M. Evans, M.Sc., for her assistance in the preparation and determination of the material. 
Phlebotomus papatasii, (Scop).

In the males twelve examples were found to possess an additional spine on the inferior clasper of the genetalia; in some instances the spine was bilateral, in other cases unilateral. One example also possessed a supernumerary spine on the left superior clasper.

India: North-west Frontier Province. Dera Ismail Khan,

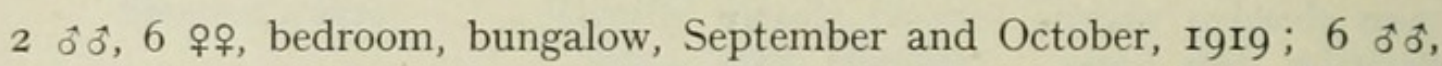
7 우, ditto, I4.iv.I920 to I4.V.I920; 40 ธิ 0 , 52 우우, cowshed, 8.iii.I920

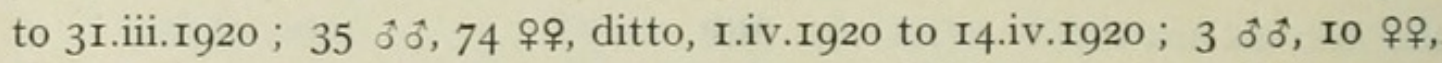
ditto, I5.iv.I920 to I5.V.I920 ; I ô, tents near I.M.S. bungalow, I6.iii.I920 ; 4 ơ ô, II $ᄋ$ 우, ditto, I2.iv.I 920 to I5.v. I 920 . TANK, I ô, 5 우, inside tents with floors sunk 3 feet, 29.viii.I9I9, I.ix.I9I9, I6.ix.I9I9; 2 우, ditto,

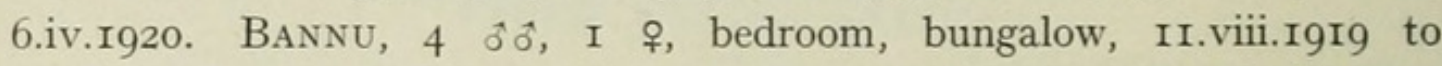
I2.viii.I9I9. IDAK, Tochi VALley, I + , mud barracks, 26.viii.rgIg. SAGgu, near Dera Ismail Khan, I우, stable, I4.iii.I920. JatTa Post, I $q$, mud barracks, 7 .iv.Igzo. MURTAZA, I ô, 4 우, mud barracks, r.ix.I9I9; I $\hat{0}, 6$ 우, ditto, 7.iv. Ig20. Hathala, I $\hat{o}$, I $q$, mud barracks, 29.viii.I9I9; I \&, ditto, 6.iv.I920.

Phlebotomus minutus, Rondani.

The specimens showed a marked variation in colour ; every form intervening between the pale typical examples and distinctly dark or melanic forms were observed. The left superior clasper in one male possessed a supernumerary spine. The wings of this species also showed a marked tendency to variation, both as regards size and contour, and also in the relative length of the anterior forked vein.

India: North-west Frontier Province. Dera Ismail Khan, II 8 ô $\hat{o}, 34$ ๆ̊, bedroom, bungalow, September and October, I9I9; 6 oิ $\hat{o}^{2}, 2$ 우, ditto, I4.iv.I920 to I 4.v.I920; 3 ô $\hat{o}, 7$ 우, cowshed, 8.iii.I920 to 3 I.iii.I920; I5 $\hat{o} \hat{o}, 8$ 워, ditto, I.iv.I920 to I4.iv.I920; I $\hat{\delta}, 3$ 우, tents near I.M.S. bungalow, I6.iii.I920; 36 oิ ô, I3 ㅇํ, ditto, I2.iv.I920 to I5.v.Ig20. TANK, 3 ô $\hat{0}, 6$ 우, tents with floors sunk 3 feet, 29.viii.IgIg, r.ix.I9I9, I6.ix.IgI9. BANnu, 37 oै $\hat{o}, 37$ 우, bedroom, bungalow, II.viii.I9I9 to I2.viii.I9I9. IDAK, TochI VALLEY, 2 ô $\hat{o}$, mud barracks,

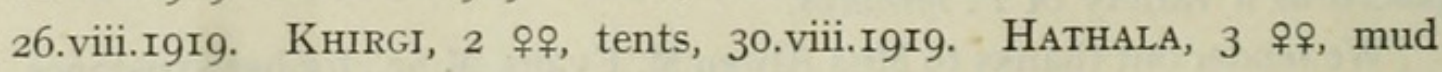
barracks, 29.viii.IgI9. 
Phlebotomus minutus var. antennatus, Newst.

Phlebotomus antennatus, Newst. Bull. Ent. Res., Vol. III, p. 365.

The variation in colour from light to dark or melanic forms was similar to that found in $P$. minutus, but none possessed the intense lapis-lazuli colour found in the West African forms. ${ }^{5}$

India : North-west Frontier Province. Dera Ismail Khan,

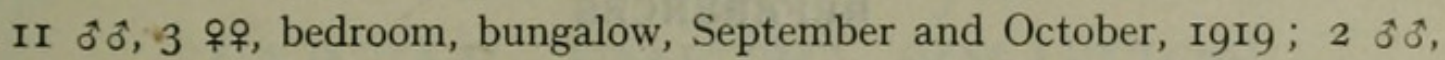

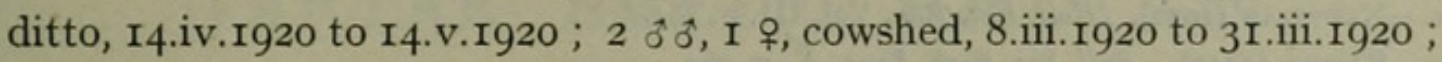
I $\hat{\delta}, 2$ 우, ditto, I.iv.I920 to I4.iv.I920; I $\hat{\delta}, 2$ 우우, tents near I.M.S. bungalow, I2.iv.I920 to I5.V.I920, TANK, 3 우, tents with floors sunk 3 feet, 29.viii.I9I9, I.ix.I9I9, I6.ix.rgI9. BANNU, 2 oิ oิ, 7 ๆ오, bedroom, bungalow, Ir.viii. I9I9, I2.viii.rgI9.

Phlebotomus sergenti, Parrot.

Parrot $^{2}$ first described this species from Algeria ; subsequently it was found by Marzinovsky ${ }^{3}$ at Tiflis, by Sinton in Persia, and by Buxton ${ }^{4}$ in Mesopotamia. Hitherto it does not seem to have been recorded from India.

India: North-west Frontier Province. Dera Ismail Khan, I $\hat{o}$, cowshed, 8.iii.I920 to 3r.iii.I920; I $\hat{o}$, tents near I.M.S. bungalow, I2.iv.I920 to I5.V.I920; 3 ô ô, I 우, stable, TANK ROAD, 7 miles from Dera Ismail Khan, 6.iv.rg20. MurtazA, I ô, mud barracks, I.ix.I9I9.

Phlebotomus major, Annandale. Records Indian Mus., Vol. V, p. 46 (IgIo).

INDIA : Simla, I 우, 30.v.I920.

Colour and general facies resembling those of the female in P.papatasii, but the wings are relatively longer and narrower. Position of abdominal hairs doubtful owing to the rubbed condition of the dorsal surface, but the hairs on the venter more or less erect. Palpi with the 2nd, 3rd, and $4^{\text {th }}$ segments sub-equal in length ; the $5^{\text {th }}$ twice the length of the $3 \mathrm{rd}$.

Total length of head and body, $3.5 \mathrm{~mm}$. ; length of wing, 3.3 ; greatest width, $\mathrm{I} \cdot 05 \mathrm{~mm}$. ; length of leg ii, $4.8 \mathrm{~mm}$.; femur more than half the length of the tibia, the latter equal in length to the first three proximal segments of the tarsus.

This, as may be gathered from the above details, is an exceptionally large species, and in its general facies and certain structural characters agrees with Annandale's description of his P. major (l.c.). There are some 
important discrepancies however : i.e., in the arrangement of the abdominal hairs, and the length of the body as compared with that of the legs. We feel, however, that these may be considered as possible mutations within the range of variation of the species, and have therefore placed it here.

\section{REFERENCES}

1.-Newstead (1912). Bull. Ent. Res., Vol. III, p. 365.

2.-Parrot (1917). Bull. Soc. Path. Exot., X, p. ${ }_{5}^{64}$.

3.-Marzinovsky (1917). Medical Review, Moscow, LXXXVII, p. 6i2.

4.-Newstead (1920). Bull. Ent. Res., Vol. XI, p. 307.

5.-_ (1920). Bull. Ent. Res., Vol. XI, p. 305. 


\section{$2 \mathrm{BHL}$ Biodiversity Heritage Library}

Newstead, R and Sinton, J A. 1921. "On a collection of pappataci flies (Phlebotomus) from India." Annals of tropical medicine and parasitology 15, 103-106. https://doi.org/10.1080/00034983.1921.11684256.

View This Item Online: https://www.biodiversitylibrary.org/item/96753

DOI: https://doi.org/10.1080/00034983.1921.11684256

Permalink: https://www.biodiversitylibrary.org/partpdf/69443

\section{Holding Institution}

University of Toronto - Gerstein Science Information Centre

\section{Sponsored by}

University of Toronto

\section{Copyright \& Reuse}

Copyright Status: Not provided. Contact Holding Institution to verify copyright status.

This document was created from content at the Biodiversity Heritage Library, the world's largest open access digital library for biodiversity literature and archives. Visit BHL at https://www.biodiversitylibrary.org. 